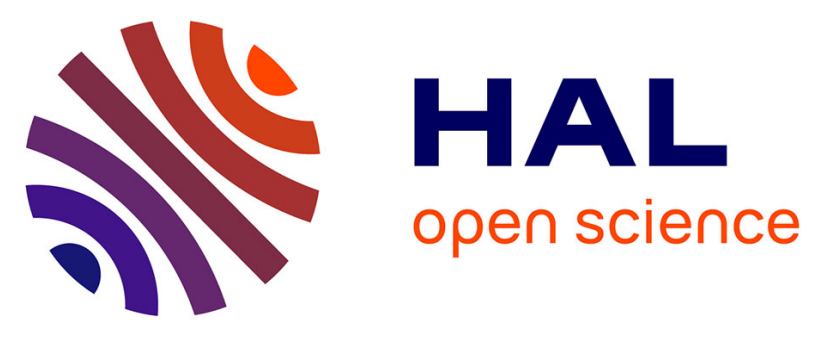

\title{
Tracking the changing oxidation state of Erebus magmas, from mantle to surface, driven by magma ascent and degassing
}

Yves Moussallam, Clive Oppenheimer, Bruno Scaillet, Fabrice Gaillard, Philip R. Kyle, Nial Peters, Margaret Hartley, Kim Berlo, Amy Donovan

\section{To cite this version:}

Yves Moussallam, Clive Oppenheimer, Bruno Scaillet, Fabrice Gaillard, Philip R. Kyle, et al.. Tracking the changing oxidation state of Erebus magmas, from mantle to surface, driven by magma ascent and degassing. Earth and Planetary Science Letters, 2014, 393, pp.200-209. 10.1016/j.epsl.2014.02.055 . insu-00966727

\section{HAL Id: insu-00966727 https://hal-insu.archives-ouvertes.fr/insu-00966727}

Submitted on 27 Mar 2014

HAL is a multi-disciplinary open access archive for the deposit and dissemination of scientific research documents, whether they are published or not. The documents may come from teaching and research institutions in France or abroad, or from public or private research centers.
L'archive ouverte pluridisciplinaire HAL, est destinée au dépôt et à la diffusion de documents scientifiques de niveau recherche, publiés ou non, émanant des établissements d'enseignement et de recherche français ou étrangers, des laboratoires publics ou privés.

\section{(ㅇ)(1) $\$$}

Distributed under a Creative Commons Attribution - NonCommercial - NoDerivatives 44.0 


\title{
Tracking the changing oxidation state of Erebus magmas, from mantle to surface, driven by magma ascent and degassing
}

Yves Moussallam ${ }^{1}$, Clive Oppenheimer ${ }^{1}$, Bruno Scaillet ${ }^{2}$, Fabrice Gaillard ${ }^{2}$, Philip Kyle ${ }^{3}$, Nial Peters ${ }^{1}$, Margaret Hartley ${ }^{4}$, Kim Berlo ${ }^{5}$, Amy Donovan ${ }^{1}$

\footnotetext{
${ }^{1}$ Department of Geography, University of Cambridge, Downing Place, Cambridge, CB2 3EN, UK

${ }^{2}$ ISTO, 7327 Université d'Orléans-CNRS-BRGM, 1A rue de la Férollerie, 45071 Orléans cedex 2, France

${ }^{3}$ Department of Earth and Environmental Science, New Mexico Institute of Mining and Technology, 801 Leroy Place, Socorro, NM 87801, USA

${ }^{4}$ Department of Earth Sciences, University of Cambridge, Downing Street, Cambridge, CB2 3EQ

${ }^{5}$ Department of Earth Sciences, University of Oxford, South Parks Road, Oxford, OX1 3AN, UK
}

Corresponding author: Yves Moussallam; ym286@cam.ac.uk; Tel: 01223 333399; Fax: 01223333392

Keywords: oxygen fugacity; sulfur; degassing; XANES; Melt inclusions; $\mathrm{CO}_{2}$

\begin{abstract}
The conventional view holds that the oxidation state of a mantle-derived degassed magma reflects its source. During magma ascent and degassing the oxidation state is thought to follow a redox buffer. While this view has been challenged by petrological data, geochemical models and volcanic gas measurements, the fingerprints of such redox changes and their driving forces have not hitherto been captured by an integrated study. Here, we track the redox evolution of an alkaline magmatic suite at Erebus volcano, Antarctica, from the mantle to the surface, using X-ray absorption near-edge structure (XANES) spectroscopy at the iron and sulphur K-edges. We find that strong reduction of $\mathrm{Fe}$ and $\mathrm{S}$ dissolved in the melt accompanies magma ascent. Using a model of gas-melt chemical equilibria, we show that
\end{abstract}


sulphur degassing is the driving force behind this evolutionary trend, which spans a wide compositional and depth range. Our results explain puzzling shifts in the oxidation state of gases emitted from Erebus volcano, and indicate that, where sulphur degassing occurs, the oxidation states of degassed volcanic rocks may not reflect their mantle source or co-eruptive gas phase. This calls for caution when inferring the oxidation state of the upper mantle from extrusive rocks and a possible re-assessment of the contribution of volcanic degassing to the early Earth's atmosphere and oceans. The relationship between magma redox conditions and pressure (depth) emphasises the value of measuring redox couples in gases emitted from volcanoes for the purposes of operational forecasting.

HIGHLIGHTS

- Melt inclusions from Erebus track a progressive reduction of the magma with ascent.

- Sulphur degassing is the driving physical process behind this change.

- Volcanic gas chemistry can be related to the gas-melt segregation depth.

\section{INTRODUCTION}

The oxidation state of an igneous system is often expressed in terms of oxygen fugacity $\left(f \mathrm{O}_{2}\right)$, an intensive thermodynamic variable. Oxygen fugacity varies widely in magmas (Frost \& McCammon, 2008) and controls phase equilibria and the composition of minerals, melt and gas. Here we examine a suite of olivine- and anorthoclase feldspar-hosted melt inclusions (MI) from basanites, tephriphonolites and phonolites from Erebus volcano and nearby Hut Point Peninsula, Antarctica (Oppenheimer et al., 2011). Erebus is an alkaline volcano that sits in an intraplate continental rift, and its uppermost phonolite magma is exposed as a persistent lava lake. We focused on these samples since they represent a near-continuous differentiation series (Kyle et al., 1992) and record depths spanning the entire crust and extending into the upper mantle (Moho depth $<20 \mathrm{~km}$ ). In addition, measurements of sustained gas emissions 
from the Erebus lava lake show they are more reduced $\left(\mathrm{fO}_{2}\right.$ around NNO-1.6, i.e., $1.6 \log$ units below the $\mathrm{Ni}-\mathrm{NiO}$ solid buffer) than gases sourced from greater depth during Strombolian eruptions ( $f \mathrm{O}_{2}$ around NNO) (Oppenheimer et al., 2011; Burgisser et al., 2012).

\section{METHODOLOGY}

Samples used in this study and their preparation are described by Eschenbacher (1998) and given in Oppenheimer et al., (2011) (see also Table S1). To ensure good preservation of MI, rapidly quenched samples from subaqueous pillow and palagonite breccias and a phonolite sample from an Erebus volcanic bomb erupted in 1997 were used. Fig.1 shows the typical morphology of melt inclusions hosted in olivine (for basanite to tephriphonolite composition) and anorthoclase (for phonolite composition) crystals. Olivine-hosted MI reach up to $350 \mu \mathrm{m}$ across and consist of brown-coloured transparent glass of ovoid and negative crystal shape located throughout the crystal. Anorthoclase-hosted MI are of irregular and negative crystal shape, reach up to $600 \mu \mathrm{m}$ across, and tend to be elongated parallel to the crystal face. Anorthoclase crystals can reach up to $10 \mathrm{~cm}$ in length. Olivine-hosted MI may contain one vapour bubble (many have none) whereas they are common in anorthoclase-hosted MI. Magnetite, apatite and pyroxene crystals are found in some MI. Pyrrhotite globules are present in MI and as mineral inclusions in all compositions. Only doubly polished wafers in which each side of the MI was polished, and at least a $20 \times 20 \mu \mathrm{m}^{2}$ area through the inclusion was free of obstructions were examined. The MI were analysed for major and volatile elements by EMP, SIMS and FTIR spectroscopy by Eschenbacher, (1998) and further discussed by Oppenheimer et al., (2011). Details are given in the supplementary information.

\subsection{XANES analytical Methods}

We used synchrotron-based Fe and S K-edge X-ray absorption near-edge structure (XANES) spectroscopy to explore the redox state of the MI using the iron $\mathrm{Fe}^{3+} / \Sigma \mathrm{Fe}$ ratio and sulphur 
speciation. Glass standards for the XANES analyses were prepared in a controlled atmosphere furnace at the Department of Earth Sciences, University of Cambridge. The furnace was operated at atmospheric pressure $(0.1 \mathrm{MPa})$, and was heated by a silicon carbide resistance wire wrapped around an aluminium cylinder. A controlled mixture of $\mathrm{CO}$ and $\mathrm{CO}_{2}$ gases was circulated through the furnace and monitored by calibrated flow meters. The current was controlled by a Eurotherm 2404 series regulator able to maintain a constant temperature $\left( \pm 2^{\circ} \mathrm{C}\right)$ within the furnace. The cooling system consists of a constant flow of water circulating within the furnace. For each experiment, $50 \mathrm{mg}$ of sample was placed in a platinum crucible. The sample was then introduced in the furnace and heated at $1400^{\circ} \mathrm{C}$ and left to equilibrate for two days. At the end of each experiment, rapid quenching preserved chemical equilibrium as the sample dropped in a container of deionised water. The drop was initiated by short-circuiting the thin platinum wire by passing a current through the thick platinum wires. Four basanite standards were equilibrated at QFM-1, QFM, NNO, NNO+1, and, while tephriphonolite standards were equilibrated at QFM-1, NNO and NNO+1. All standard glasses were analysed by electron microprobe. A 15-point-transect was made across each standard to ensure all samples were homogeneous and to monitor iron and sodium loss.

Micro X-ray Absorption Near-Edge Structure ( $\mu$-XANES) spectroscopy is a synchrotronbased method able to determine the valence state of elements in a range of materials including glass and crystals. XANES analyses at the Fe K-edge were conducted from 6987 to $7350 \mathrm{eV}$, using a $3 \times 2 \mu \mathrm{m}^{2} \mathrm{x}$-ray beam whereas analyses at the $\mathrm{S} \mathrm{K}$-edge were conducted from 2400 to $2675 \mathrm{eV}$ using a $5 \times 5 \mu \mathrm{m}^{2} \mathrm{X}$-ray beam (Table S2). Both sets of analyses were acquired during a single week at beamline I18 of the Diamond Light Source (in the UK). The storage ring was operated at an energy of $3 \mathrm{GeV}$ with electron currents of $300 \mathrm{~mA}$. The X-ray beam was monochromatised by a pair of Si (111) crystals (for measurements at both 
the $\mathrm{S}$ and Fe K-edges). Measurements were performed in fluorescence mode. The incident monochromatic X-ray intensity (I0) was measured with a $1.5 \mathrm{~cm}$-long ionization chamber. The fluorescence intensity (IF) was measured with a four-element silicon drift detector positioned perpendicularly to the beam direction. The sample was oriented at $45^{\circ}$ to the incident beam. For analyses at the S K-edge, the sample chamber was flushed with helium to minimise the attenuation of the fluorescence radiation. The ionisation chamber was flushed with helium for both $\mathrm{S}$ and Fe K-edge measurements. Energy resolution is estimated at 0.1 $\mathrm{eV}$. The pre-edge feature (7110-7118 eV) on a XANES spectrum at the Fe K-edge corresponds to the $1 \mathrm{~s} \rightarrow 3 \mathrm{~d}$ electronic transition. The pre-edge region was fitted using a combination of a linear function and a damped harmonic oscillator function (DHO) to fit the baseline, on to which were superimposed two Gaussians to fit the two pre-edge peaks (Cottrell et al., 2009) (Fig.S2). This method has the advantage of reproducing the spectrum extremely well (with a very low residual). We used the centroid (area-weighted average) of the two Gaussians to parameterise against the Fe valence state. We constructed calibration curves using the basanite, and tephriphonolite standards (Fig. S3 and S4). Instrumental drift was small since all Fe K-edge spectra were acquired in a $24 \mathrm{~h}$ period and corrected by aligning the pre-edge region of all spectra to that of the corresponding glass standard. Spectral alignment was achieved by matching the first peak on the derivative spectra (at 7111 $\mathrm{eV}$ ), equivalent to matching the initial rise of the pre-edge region in normalised intensity (Fig. S5). All XANES spectra were examined for contamination from the olivine host. Spectra showing any structure in the edge and post edge region (see Fig S6 for an example) were not processed.

\subsection{Beam damage}

The focus beam of X-rays can cause photo-reduction of the sulphur (Wilke et al., 2008; Métrich et al., 2009). To assess this effect we subjected a phonolitic anorthoclase-hosted melt 
inclusion to long beam exposure by acquiring four successive spectra. This sample had not been subjected to EMPA prior to XANES analysis. Figure S7 shows that the sulphur was, in fact, oxidized under the X-ray beam. We therefore expect all S K-edge spectra of glasses analyzed in this study to have undergone some amount of oxidation under the beam. We note however that the exposure time to the beam has been similar for all MI and the large differences in the spectra between each sample group cannot be solely attributed to beam damage. The transition at $\sim 2478.4 \mathrm{eV}$ typical of $\mathrm{S}^{4+}$ shown by sample DVDP 3-295 is likely to be an analytical artefact as discussed in Wilke et al., (2008).

\subsection{Determination of the $\mathrm{Fe}^{3+} / \sum \mathrm{Fe}$ ratio}

The standard equation to relate $f \mathrm{O}_{2}$ and temperature to $\mathrm{Fe}^{3+} / \sum \mathrm{Fe}$ is given by (Kress \& Carmichael, 1991):

$\ln \left(\frac{X F e_{2} O_{3}}{X F e O}\right)=a \ln \left(f O_{2}\right)+\frac{b}{T}+c+\sum d_{\mathrm{i}} X_{\mathrm{i}}$

where $a=0.196, b=11492, \mathrm{c}=-6.675, d_{\mathrm{Al} 2 \mathrm{O} 3}=-2.243 d_{\mathrm{FeO}}=-1.828, d_{\mathrm{Na} 2 \mathrm{O}}=5.854, d_{\mathrm{K} 2 \mathrm{O}}=6.215$ and $d_{\mathrm{CaO}}=3.201$. This equation was tested using experimental data from the literature, whose compositions closely matched that of the basanite MI from sample DVDP3-295. We used samples 10 and 27 from Sack et al., (1981), samples 141 and 142 from (Kress \& Carmichael, 1988) and sample U-50 from Kilinc et al., (1983). We found that the calculated $\mathrm{Fe}^{3+} / \sum \mathrm{Fe}$ ratio was consistently overestimated by the calculation compared to the measured value. We therefore made a slight correction to equation (1) adjusting parameters $b$ and $c$ in order to minimise the difference between calculated and measured data. We thereby found that the experimental data were best reproduced using $b=11357.9$ and $c=-6.7542$ (the other constants were left unchanged). The original parameterisation of Equation (1) was not modified for the tephriphonolite composition.

Standards were analysed by wet chemistry at the ISTO-CNRS laboratory in Orléans (Table S3); the difference between calculated and measured values is shown in Fig. S4. The 
resulting calibration curves are slightly different and not within error of each other. The discrepancy between the two calibration methods reflects an important uncertainty on the absolute $\mathrm{Fe}^{3+} / \Sigma \mathrm{Fe}$ ratio reported. We chose here to use the calibration curve given from calculated values as they are obtained directly from the imposed $f_{2}$ under which the standards were created whereas wet chemistry represents a bulk method that can be affected by uneven amounts of iron loss in the glass standards. Wet chemistry analyses, therefore, do not provide an accurate estimate of the $\mathrm{Fe}^{3+} / \Sigma \mathrm{Fe}$ ratio of the synthetic glasses used as standard. The effect of using the calibration curve from wet chemistry in subsequent figures is illustrated in Fig S8.

\subsection{Gas-melt equilibrium modelling}

The model used in this study (Gaillard \& Scaillet, 2009; Gaillard et al., 2011) solves, at each pressure step, the following reactions in the $\mathrm{C}-\mathrm{H}-\mathrm{S}-\mathrm{O}$ system, at magmatic pressure and temperature:

$$
\begin{aligned}
& \mathrm{CO}_{(\text {gas })}+1 / 2 \mathrm{O}_{2}=\mathrm{CO}_{2 \text { (gas) }} \\
& \mathrm{H}_{2 \text { (gas) }}+1 / 2 \mathrm{O}_{2}=\mathrm{H}_{2} \mathrm{O}_{\text {(gas) }} \\
& \mathrm{CH}_{4(\text { gas })}+\mathrm{O}_{2}=\mathrm{CO}_{2 \text { (gas) }}+2 \mathrm{H}_{2} \mathrm{O}_{(\text {gas })} \\
& 1 / 2 \mathrm{~S}_{2 \text { (gas) }}+\mathrm{O}_{2}=\mathrm{SO}_{2 \text { (gas) }} \\
& 1 / 2 \mathrm{~S}_{2 \text { (gas) }}+\mathrm{H}_{2} \mathrm{O}_{\text {(gas) }}=\mathrm{H}_{2} \mathrm{~S}_{(\text {gas })}+1 / 2 \mathrm{O}_{2}
\end{aligned}
$$

The gas-melt equilibria (using thermodynamic data for water and carbon dioxide (IaconoMarziano et al., 2012), sulphur (O’Neill \& Mavrogenes, 2002) and hydrogen (Gaillard et al., 2003)) are dictated by the following reactions:

$$
\begin{aligned}
& \mathrm{H}_{2} \mathrm{O}_{(\text {gas })}+\mathrm{O}^{2-}{ }_{\text {(melt) }}=2 \mathrm{OH}^{-}{ }_{\text {(melt })} \\
& \mathrm{CO}_{2 \text { (gas) }}+\mathrm{O}^{2-}{ }_{\text {(melt) }}=\mathrm{CO}_{3}{ }^{2-}{ }_{\text {(melt })} \\
& \mathrm{S}_{2 \text { (gas) }}+2 \mathrm{O}^{2-}{ }_{\text {(melt) }}=\mathrm{O}_{2}+2 \mathrm{~S}^{2-}{ }_{\text {(melt) }} \\
& \mathrm{H}_{2 \text { (gas) }}=\mathrm{H}_{2 \text { (melt) }}
\end{aligned}
$$


The iron redox ratio in the melt is computed using Equation (1) for the tephriphonolite and phonolite, and its slightly modified form for the basanite. Note that the increment of pressure steps in the calculations has no effect on the results since thermodynamic equilibrium depends only on the pressure and temperature considered.

\section{RESULTS}

\subsection{XANES at the Fe K-edge}

The XANES results of iron at its K-edge are reported in Tables 2 and 3; example spectra are presented in Fig. 2; and the results are shown in Fig. 3. The results indicate pronounced reduction of iron (lower $\mathrm{Fe}^{3+} / \Sigma \mathrm{Fe}$ ratio) with decreasing pressure. This pattern holds for MI of similar composition but different entrapment pressure, suggesting that the identified redox change with depth is not simply a reflection of differentiation, crystallisation or crustal assimilation. Furthermore, for samples in which it was analysed, the quenched matrix glass records a $\mathrm{Fe}^{3+} / \Sigma \mathrm{Fe}$ ratio systematically lower than that of the coexisting MI.

\subsection{XANES at the S K-edge}

The XANES spectra of sulphur at its K-edge remain difficult to interpret quantitatively (Rowe et al., 2007; Wilke et al., 2008; Métrich et al., 2009) as discussed above, but provide useful qualitative information on the nature of dissolved $\mathrm{S}$ species. Fig. 4 shows $\mathrm{S}$ spectra for each sample group. All spectra show an absorption edge crest at $\sim 2477 \mathrm{eV}$ and a poorlyresolved shoulder at $\sim 2474 \mathrm{eV}$, typical of the presence of $\mathrm{S}^{2-}$ species in the glass and in agreement with the presence of pyrrhotite globules, $<3 \mu \mathrm{m}$ in diameter, in MI from all samples This structure is most pronounced in AW82033 (basanite) and least in DVDP3-295 (basanite). Basanite sample DVDP3-295 shows an intense transition at $2478.4 \mathrm{eV}$ characteristic of the sulphite anion $\left(\mathrm{SO}_{3}{ }^{2-}\right)$. Both DVDP 3-295 and tephriphonolite sample 97009 show a very strong transition at $(\sim 2482.6 \mathrm{eV})$ typical of sulphate anions $\left(\mathrm{SO}_{4}{ }^{2-}\right)$ while 
other samples show a less pronounced transition at this energy level and AW82033 (basanite) from more shallow depths shows almost no sulphate signal.

Samples 97018 (phonolite), 97010 (tephriphonolite), 97011 (phonolite) and to a lesser extent 97009 and AW82033 show a transition at $2471.2 \mathrm{eV}$ representative of $\mathrm{S}^{2-}$ species in the glass. Another transition occurs at $\sim 2467 \mathrm{eV}$ in samples 97009, 97010, 97011 and most strongly in 97018. We could not match this transition with any sulphur-bearing mineral standards but note that it is similar to a peak observed in reduced, iron-free glass spectra from Métrich et al., (2009). While these MI samples all show some oxidation has occurred under the X-ray beam, samples DVDP3-295 and 97009 are, nevertheless, significantly more oxidised (higher sulphate signals) than samples 97010, 97011, AW82033 and 97018 (which have a stronger $\mathrm{S}^{2-}$ signal). Since most MI in DVDP3-295 and 97009 were entrapped at higher pressure compared with the other samples, the S K-edge analyses are consistent with the reducing trend associated with magma decompression evident in the Fe K-edge spectra.

\section{DISCUSSION AND MODELLING}

Several mechanisms have been proposed to explain changing redox state in magmas during ascent and/or differentiation. In an earlier study of Erebus (Oppenheimer et al., 2011), a linear decrease of $\mathrm{FeO} / \mathrm{Fe}_{2} \mathrm{O}_{3}$ with decreasing pressure (from NNO+0.4 at $800 \mathrm{MPa}$ to NNO0.6 at $0.1 \mathrm{MPa}$ ) was modelled and attributed to the precipitation of olivine, pyroxene and magnetite. However, this presupposes that magmatic differentiation occurs continuously with decreasing pressure, which cannot explain the strong variation of $\mathrm{Fe}^{3+} / \Sigma \mathrm{Fe}$ in $\mathrm{MI}$ of the same composition. We can exclude magnetite precipitation as the driving force behind the observed reducing trend since there is no correlation between the melt iron content and its redox state (Fig. S9). The absence of correlation between the melt $\mathrm{Mg}$ number and its 
$\mathrm{Fe}^{3+} / \Sigma \mathrm{Fe}$ ratios (Fig. S10) also shows that there is no obvious change in redox with differentiation. This is evident when considering that the tephriphonolites, which are differentiated from the basanite, have very similar oxidation state and $\mathrm{Fe}^{3+} / \Sigma \mathrm{Fe}$ ratio to the undegassed basanites. It is therefore clear that precipitation of Fe-bearing minerals only exerts a second order influence on the melt redox state. Importantly, our dataset counters the idea that MI will requilibrate with redox changes in the host magma on such rapid timescales that they cannot reflect the source (e.g. Gaetani et al., 2012; Bucholz et al., 2013). It is clear from our data that olivine-hosted MI retain their signature even when the crystals have been in contact with melt and gases at a different redox state.

We propose that $f \mathrm{O}_{2}$ is controlled by coupled redox reactions between sulphur and iron in the silicate melt and coexisting gas phase (Carmichael \& Ghiorso, 1986). Sulphur dissolves in the melt as sulphate $\left(\mathrm{S}^{6+}\right)$ or sulphide $\left(\mathrm{S}^{2-}\right)$ but is present in the gas phase as $\mathrm{SO}_{2}\left(\mathrm{~S}^{4+}\right)$ or $\mathrm{H}_{2} \mathrm{~S}$ $\left(\mathrm{S}^{2-}\right)$ (Métrich et al., 2009). The exsolution of sulphur can therefore be accompanied by reduction (e.g., six electrons are liberated with $\mathrm{S}^{2-} \rightarrow \mathrm{S}^{4+}$ ) or oxidation (two electrons are captured with $\mathrm{S}^{6+} \rightarrow \mathrm{S}^{4+}$ ) of dissolved iron, which is the only other major multiple valence state element in the melt, following reactions such as (Métrich et al., 2009):

$\mathrm{S}^{2-}$ (melt) $+\mathrm{Fe}^{3+}{ }_{2} \mathrm{O}_{3 \text { (melt) }}=\mathrm{SO}_{2 \text { (gas) }}+6 \mathrm{Fe}^{2+} \mathrm{O}_{\text {(melt) }}+\mathrm{O}^{2-}$ (melt)

and

$\mathrm{SO}_{4}{ }^{2-}{ }_{\text {(melt })}+2 \mathrm{Fe}^{2+} \mathrm{O}_{\text {(melt) }}=\mathrm{SO}_{2 \text { (gas) }}+\mathrm{Fe}^{3+}{ }_{2} \mathrm{O}_{3 \text { (melt) }}+\mathrm{O}^{2-}{ }_{\text {(melt) }}$

In addition, $\mathrm{SO}_{2}$ degassing is increasingly favoured over $\mathrm{H}_{2} \mathrm{~S}$ during magma ascent, since the following equilibrium shifts to the left with reducing pressure (Gaillard et al., 2011):

$\mathrm{SO}_{2}+3 \mathrm{H}_{2}=2 \mathrm{H}_{2} \mathrm{O}+\mathrm{H}_{2} \mathrm{~S}$

The pronounced increase of $\mathrm{Fe}^{3+} / \mathrm{Fe}^{2+}$ with pressure suggests that reaction (11) is favoured over reaction (12) during decompression. 
To test this interpretation, we modified a gas-melt equilibrium model (Gaillard \& Scaillet, 2009) to simulate the effect of sulphur degassing on iron speciation. To ensure internal consistency of the model, the entrapment pressures of the MI were recalculated using the same solubility laws on which the model is based. It is also more appropriate for alkaline composition than that used in Oppenheimer et al. (2011), which substantially underestimates $\mathrm{CO}_{2}$ solubility for these compositions. This results in slightly shallower estimates of entrapment depths for evolved compositions than previously reported (Oppenheimer et al., 2011) (Figure 3C). . The model starting conditions are reported in Table 4 and degassing is simulated from the less degassed magma without adjustment of the model for lower pressure calculations. Figs. 5, 6 and 7 show the results of this gas-melt equilibrium model for basanitic, tephriphonolitic and phonolitic compositions. To first order, the $\mathrm{Fe}^{3+} / \Sigma \mathrm{Fe} v s$. pressure trend is fitted well by the model showing that, during ascent and degassing, the redox state of the magma can evolve by two log units (from NNO+1 to NNO-1.2) for the basanite model. We note also that the model reproduces the reverse L-shaped pattern defined by the MI, with most of the reduction taking place at shallow pressure, as expected for a degassing-driven process but also reflecting that $\mathrm{SO}_{2}$ exsolution is favoured over $\mathrm{H}_{2} \mathrm{~S}$ at shallow depths.

Comparing the sulphur content of MI and matrix glasses relative to their $\mathrm{Fe}^{3+} / \Sigma \mathrm{Fe}$ ratios, both the basanite and phonolite models reproduce the observations quite well. The fit to the tephriphonolite data is poorer, likely reflecting the limited experimental data on sulphur solubility in magmas of this composition, and possibly secondary processes that influence either parameter (sulphur content or redox state). To a first order, however, it is clear that the matrix glass for this composition shows both lower sulphur content and a more reduced character compared to the corresponding melt inclusions, as predicted by the model. The 
models suggest that decompression and degassing alone can account for the observed evolution of the Erebus magmas' redox state, throughout the compositional lineage. At Erebus, this process is promoted by the relatively oxidising conditions of the primitive magmas (hence the high abundance of $\mathrm{Fe}_{2} \mathrm{O}_{3}$, which is the source of oxygen needed to oxidise $\mathrm{S}^{2-}$ in the melt to $\mathrm{S}^{4+}$ in the gas (Equation 11), and the abundance of sulphur.

The oxidised character of the most primitive magma $(\sim \mathrm{NNO}+1)$ suggests a minimum for the oxidation state of the upper mantle beneath Erebus. This estimate is at the upper end of the range obtained from oxythermobarometry measurements of spinel-bearing peridotites (Frost \& McCammon, 2008), and is more typically associated with subduction zone environments. Such high $f^{\mathrm{O}_{2}}$ might, in part, be explained by coupling of the oxidation state of spinel peridotite in rift environments to melt depletion and possibly $\mathrm{CO}_{2}$ content, with increasing degrees of melt extraction and higher $\mathrm{CO}_{2}$ content associated with more oxidised mantle (Foley et al., 2006). This is consistent with the very high abundance of $\mathrm{CO}_{2}$ in the most primitive basanitic MI (>8000 ppm).

At Erebus, measurements of redox conditions recorded in MI and the average low oxidation state of volcanic gas emissions at the surface, independently point to a magmatic system that becomes progressively reduced towards the surface. Our model (Fig. 7) helps reconcile the puzzling observation that gases fuelling sporadic Strombolian eruptions through the lava lake are more oxidised $\left(\mathrm{CO}_{2} / \mathrm{CO}\right.$ up to 100$)$ than the lake itself $\left(\mathrm{NNO}-1.6 ; \mathrm{CO}_{2} / \mathrm{CO}=15\right.$ (Burgisser et al., 2012)). These bursts are thought to arise from sudden ascent of gas that has accumulated at localised asperities in the plumbing system. Their rapid ascent and size hinders re-equilibration with the melt (i.e., Equation 11), thereby preserving their deeper, oxidised character. From our model, such oxidised compositions would be in equilibrium at a 
pressure of up to $\sim 35 \mathrm{MPa}(\sim 1.3 \mathrm{~km}$ depth; Fig.7). However, if the gas slugs cool by adiabatic expansion (Burgisser et al., 2012) then depths could be as shallow as $\sim 80 \mathrm{~m}$. This range brackets the depth of the seismic source associated with Strombolian eruptions at Erebus, of about $400 \mathrm{~m}$ (Aster et al., 2008).

\section{CONCLUSIONS}

Although this study has focused on an alkaline system with a lava lake, the mechanism proposed here should apply to any iron-bearing magma rich in sulphur and other volatiles, and in particular $\mathrm{CO}_{2}$, which will drive fluid exsolution during decompression (Wallace, 2001; Metrich \& Wallace, 2008). We thus expect a similar trend to be found not only in other rift and intraplate volcanic settings but also in volcanic arc settings (Kelley and Cottrell, 2012). At a global scale, changes in volcanic degassing pressure could therefore have the potential to affect the atmosphere's redox state (e.g. Gaillard et al., 2011). Many prior studies have used the redox state of erupted lavas of known age to model the evolution of the mantle's oxidation state and the composition of volcanic gases expelled into the atmosphere over geological time (e.g. Kasting et al., 1993; Canil, 1997; Delano, 2001). The estimated volcanic inputs have, in turn, been used to model the evolution of the Earth's early atmosphere and ocean chemistry, and thereby to infer aspects of biotic evolution (e.g. Canfield, 2005; Shaw, 2008; Sleep and Bird, 2008). Our findings suggest that the fundamental premise underlying these interpretations may not be valid, and that degassing conditions may be as influential as mantle processes in determining the oxidation state of volcanic gases.

We do stress, however, that systems which are not degassing sulphur have the potential to remain unaltered in terms of their redox during magma ascent. Indeed, cases where redox change with ascent is limited have been documented (Crabtree and Lange, 2012). On the 
other hand, recognising that the redox state of a magma can be a function of depth is a key in relating gas emission measurements to their source region. This connection presents new opportunities for geochemists engaged in measurement and interpretation of redox-sensitive gas couples at active volcanoes (Allard et al., 2005; Aiuppa et al., 2007), and for the application of gas geochemistry to volcano monitoring and hazard assessment.

\section{ACKNOWLEDGEMENTS}

This work would not have been possible without the meticulous preparation of the MI samples by Al Eschenbacher while a student at NM Tech. We thank the Diamond Light Source for access to beamline I18 (proposal number SP8219-1) that contributed to the results presented here and Tina Geraki and Konstantin Ignatyev for their help. YM acknowledges support from the University of Cambridge Home and EU Scholarship Scheme and from the Philip Lake and William Vaughan Lewis funds of the Department of Geography, University of Cambridge. CO and PK acknowledge support from the NSF and United States Antarctic Program (grant ANT1142083). F.G. acknowledges the European Research Council for funding support (ERC grant number 279790). We are most grateful to the two reviewers of the manuscript, Nicole Metrich and Elizabeth Cottrell, for their insightful comments on the manuscript.

\section{REFERENCES}

Aiuppa, A., Moretti, R., Federico, C., Giudice, G., Gurrieri, S., Liuzzo, M., Papale, P., Shinohara, H., Valenza, M., 2007. Forecasting Etna eruptions by real-time observation of volcanic gas composition. Geology 35, 1115-1118.

Allard, P., Burton, M., Muré, F., 2005. Spectroscopic evidence for a lava fountain driven by previously accumulated magmatic gas. Nature 433, 407-410.

Aster, R., Zandomeneghi, D., Mah, S., McNamara, S., Henderson, D. B., Knox, H., Jones, K., 2008. Moment tensor inversion of very long period seismic signals from Strombolian eruptions of Erebus Volcano. J. Volcanol. Geotherm. Res. 177, 635-647. 
Bucholz, C. E., Gaetani, G. A., Behn, M. D., Shimizu, N., 2013. Post-entrapment modification of volatiles and oxygen fugacity in olivine-hosted melt inclusions. Earth Planet. Sci. Lett. 374, 145-155.

Burgisser, A., Oppenheimer, C., Alletti, M., Kyle, P., Scaillet, B., Carroll, M., 2012. Backward tracking of gas chemistry measurements at Erebus volcano. Geochem. Geophys. Geosystems 13.

Canfield, D. E., 2005. The early history of atmospheric oxygen: Homage to Robert M. Garrels. Annu. Rev. Earth Planet. Sci. 33, 1-36.

Canil, D., 1997. Vanadium partitioning and the oxidation state of Archaean komatiite magmas. Nature 389, 842-845.

Carmichael, I. S. E., Ghiorso, M. S., 1986. Oxidation-reduction relations in basic magma: a case for homogeneous equilibria. Earth Planet. Sci. Lett. 78, 200-210.

Cottrell, E., Kelley, K. A., Lanzirotti, A., Fischer, R. A., 2009. High-precision determination of iron oxidation state in silicate glasses using XANES. Chem. Geol. 268, 167-179.

Crabtree, S. M., Lange, R. A., 2012. An evaluation of the effect of degassing on the oxidation state of hydrous andesite and dacite magmas: a comparison of pre- and posteruptive Fe2+ concentrations. Contrib. Mineral. Petrol. 163, 209-224.

Delano, J. W., 2001. Redox history of the Earth's interior since approximately 3900 Ma: implications for prebiotic molecules. Orig. Life Evol. Biosphere J. Int. Soc. Study Orig. Life 31, 311-341.

Eschenbacher, A., 1998. Open-system degassing of a fractionating, alkaline magma, Mount Erebus, Ross Island, Antarctica

Foley, S. F., Andronikov, A. V., Jacob, D. E., Melzer, S., 2006. Evidence from Antarctic mantle peridotite xenoliths for changes in mineralogy, geochemistry and geothermal gradients beneath a developing rift. Geochim. Cosmochim. Acta 70, 3096-3120.

Frost, D. J., McCammon, C. A., 2008. The Redox State of Earth's Mantle. Annu. Rev. Earth Planet. Sci. 36, 389-420.

Gaetani, G. A., O'Leary, J. A., Shimizu, N., Bucholz, C. E., Newville, M., 2012. Rapid reequilibration of $\mathrm{H} 2 \mathrm{O}$ and oxygen fugacity in olivine-hosted melt inclusions. Geology 40, 915-918.

Gaillard, F., Scaillet, B., 2009. The sulfur content of volcanic gases on Mars. Earth Planet. Sci. Lett. 279, 34-43.

Gaillard, F., Scaillet, B., Arndt, N. T., 2011. Atmospheric oxygenation caused by a change in volcanic degassing pressure. Nature 478, 229-232. 
Gaillard, F., Schmidt, B., Mackwell, S., McCammon, C., 2003. Rate of hydrogen-iron redox exchange in silicate melts and glasses. Geochim. Cosmochim. Acta 67, 2427-2441.

lacono-Marziano, G., Morizet, Y., Le Trong, E., Gaillard, F., 2012. New experimental data and semi-empirical parameterization of $\mathrm{H} 2 \mathrm{O}-\mathrm{CO} 2$ solubility in mafic melts. Geochim. Cosmochim. Acta 97, 1-23.

Jugo, P. J., Wilke, M., Botcharnikov, R. E., 2010. Sulfur K-edge XANES analysis of natural and synthetic basaltic glasses: Implications for $\mathrm{S}$ speciation and $\mathrm{S}$ content as function of oxygen fugacity. Geochim. Cosmochim. Acta 74, 5926-5938.

Kasting, J. ., Eggler, D. ., Raeburn, S. ., 1993. Mantle Redox Evolution and the Oxidation State of the Archean Atmosphere. J. Geol. 101, 245-257.

Kelley, K. A., Cottrell, E., 2012. The influence of magmatic differentiation on the oxidation state of Fe in a basaltic arc magma. Earth Planet. Sci. Lett. 329-330, 109-121.

Kilinc, A., Carmichael, I. S. E., Rivers, M. L., Sack, R. O., 1983. The ferric-ferrous ratio of natural silicate liquids equilibrated in air. Contrib. Mineral. Petrol. 83, 136-140.

Kress, V. C., Carmichael, I. S. E., 1988. Stoichiometry of the iron oxidation reaction in silicate melts. Am. Mineral. 73, 1267-1274.

Kress, V. C., Carmichael, I. S. E., 1991. The compressibility of silicate liquids containing Fe2O3 and the effect of composition, temperature, oxygen fugacity and pressure on their redox states. Contrib. Mineral. Petrol. 108, 82-92.

Kyle, P. R., Moore, J. A., Thirlwall, M. F., 1992. Petrologic Evolution of Anorthoclase Phonolite Lavas at Mount Erebus, Ross Island, Antarctica. J. Petrol. 33, 849-875.

Métrich, N., Berry, A. J., O'Neill, H. S. C., Susini, J., 2009. The oxidation state of sulfur in synthetic and natural glasses determined by $\mathrm{X}$-ray absorption spectroscopy. Geochim. Cosmochim. Acta 73, 2382-2399.

Metrich, N., Wallace, P. J., 2008. Volatile Abundances in Basaltic Magmas and Their Degassing Paths Tracked by Melt Inclusions. Rev. Mineral. Geochem. 69, 363-402.

Moussallam, Y., Oppenheimer, C., Aiuppa, A., Giudice, G., Moussallam, M., Kyle, P., 2012. Hydrogen emissions from Erebus volcano, Antarctica. Bull. Volcanol. 74, 2109 2120.

O'Neill, H. S. C., Mavrogenes, J. A., 2002. The Sulfide Capacity and the Sulfur Content at Sulfide Saturation of Silicate Melts at $1400^{\circ} \mathrm{C}$ and 1 bar. J. Petrol. 43, 1049-1087.

Oppenheimer, C., Moretti, R., Kyle, P. R., Eschenbacher, A., Lowenstern, J. B., Hervig, R. L., Dunbar, N. W., 2011. Mantle to surface degassing of alkalic magmas at Erebus volcano, Antarctica. Earth Planet. Sci. Lett. 306, 261-271. 
Rowe, M. C., Kent, A. J. R., Nielsen, R. L., 2007. Determination of sulfur speciation and oxidation state of olivine hosted melt inclusions. Chem. Geol. 236, 303-322.

Sack, R. O., Carmichael, I. S. E., Rivers, M., Ghiorso, M. S., 1981. Ferric-ferrous equilibria in natural silicate liquids at 1 bar. Contrib. Mineral. Petrol. 75, 369-376.

Scheinost, A., Hennig, C., Somogyi, A., Martinez-Criado, G., Knappik, R., 2006. Geochemical behavior of uranium in mine tailings at Freital, Germany: A mu-XRF, mu-XAFS and mu-XRD study. Geochim. Cosmochim. Acta 70, A560.

Shaw, G. ., 2008. Earth's atmosphere - Hadean to early Proterozoic. Chem. Erde - Geochem. 68, 235-264.

Sleep, N. ., Bird, D. ., 2008. Evolutionary ecology during the rise of dioxygen in the Earth's atmosphere. Philos. Trans. R. Soc. B Biol. Sci. 363, 2651 -2664.

Wallace, P. J., 2001. Volcanic SO2 emissions and the abundance and distribution of exsolved gas in magma bodies. J. Volcanol. Geotherm. Res. 108, 85-106.

Wilke, M., Jugo, P. J., Klimm, K., Susini, J., Botcharnikov, R., Kohn, S. C., Janousch, M., 2008. The origin of S4 detected in silicate glasses by XANES. Am. Mineral. 93, 235-240.

\section{AUTHOR COMTRIBUTIONS}

Y.M. designed and performed the synchrotron experiments, analysed data, performed the modelling and wrote the paper. P.K. provided all the samples and MI maps. C.O., B.S. and P.K. supervised the project and wrote the paper. F.G. designed the modelling and wrote the paper. N.P., M.H., K.B. and A.D. performed the synchrotron experiments. N.P. developed the fitting algorithm for XANES spectra.

\section{FIGURE CAPTION}

Figure 1: A. Transmitted light photomicrograph of an olivine hosted melt inclusion. B. X-ray potassium chemical map of anorthoclase hosted melt inclusions.

Figure 2: Example of edge-step normalised XANES spectra. A. Example spectra from two matrix glass and three melt inclusions from a basanite sample (DVDP-3-295). B. Example spectra from four tephra-phonolite and four phonolite melt inclusions (samples 97009 and 97018 respectively). C. Example spectra from DVDP-3-295 basanitic melt inclusions compared to a basanite standard equilibrated at conditions near NNO+1. D. Example spectra from 97018 phonolitic melt inclusions compared to a tephra-phonolite standard equilibrated at conditions near QFM-1.

Figure 3: A. Plot of $\mathrm{CO}_{2}$ concentration (in ppm; determined by FTIR (Oppenheimer et al., 2011)) compared to $\mathrm{Fe}^{3+} / \Sigma \mathrm{Fe}$ ratio determined by $\mathrm{Fe}$ K-edge XANES. B. Plot of $\mathrm{H}_{2} \mathrm{O}$ concentration (in wt\%; determined by FTIR (Oppenheimer et al., 2011)) compared to $\mathrm{Fe}^{3+} / \Sigma \mathrm{Fe}$ ratio determined by $\mathrm{Fe} \mathrm{K}$-edge XANES. Error bars on $\mathrm{CO}_{2}$ and $\mathrm{H}_{2} \mathrm{O}$ measurements are from Oppenheimer et al., (2011); errors in the $\mathrm{Fe}^{3+} / \Sigma \mathrm{Fe}$ ratio are discussed in the SI. C. 
Plot of $\mathrm{Fe}^{3+} / \Sigma \mathrm{Fe}$ ratio determined by $\mathrm{Fe} \mathrm{K}$-edge XANES spectroscopy compared with calculated entrapment pressures (Oppenheimer et al., 2011) for each melt inclusion. The lava lake $\mathrm{Fe}^{3+} / \Sigma \mathrm{Fe}$ ratio is computed from measurements of the $\mathrm{CO} / \mathrm{CO}_{2}$ and $\mathrm{H}_{2} / \mathrm{H}_{2} \mathrm{O}$ ratios in the gases emitted from Erebus' lava lake (Oppenheimer et al., 2011, Moussallam et al., 2012).

Figure 4: S K-edge XANES spectra for each sample studied (averages for four or five individual MI spectra are shown). The dashed lines are at $2482.6 \mathrm{eV}\left(\mathrm{S}^{6+}\right), 2478.4 \mathrm{eV}\left(\mathrm{S}^{4+}\right)$, $2477.0 \mathrm{eV}\left(\mathrm{S}^{2-}\right)$ and $2471.2 \mathrm{eV}\left(\mathrm{S}^{2-}\right)$. Anhydrite $\left(\mathrm{S}^{6+}\right)$ (Scheinost et al., 2006)), sodium sulfite $\left(S^{4+}\right)(J u g o$ et al., 2010$)$ ) and pyrrhotite $\left(S^{2-}\right)$ spectra are given for reference (available from the ESRF database http://www.esrf.eu/UsersAndScience/Experiments/Imaging/ID21/php).

Figure 5: A. Plot of $\mathrm{Fe}^{3+} / \Sigma \mathrm{Fe}$ ratios determined by $\mathrm{Fe}$ K-edge XANES spectroscopy compared with calculated entrapment pressures (this study) for each melt inclusion. See Figure 3 for derivation of the lava lake $\mathrm{Fe}^{3+} / \Sigma \mathrm{Fe}$ ratio. The results of gas-melt equilibrium modelling are shown for basanite (blue curve), tephriphonolite (yellow curve) and phonolite (red curve) compositions. B. Plot of $\triangle \mathrm{NNO}$ value determined by $\mathrm{Fe}$ K-edge XANES spectroscopy compared with calculated entrapment pressures (this study) for each melt inclusion. Error bars on the entrapment depth are based on uncertainties in $\mathrm{CO}_{2}$ measurements. A more realistic error on the calculated pressure would also take account of the error on $\mathrm{H}_{2} \mathrm{O}, \mathrm{S}, f \mathrm{O}_{2}$ and solubility laws and cannot readily be computed. Errors in $\mathrm{Fe}^{3+} / \Sigma \mathrm{Fe}$ ratios are discussed in the SI.

Figure 6: Plot of $\mathrm{Fe}^{3+} / \Sigma \mathrm{Fe}$ ratio determined by $\mathrm{Fe} \mathrm{K}$-edge XANES compared to measured sulphur contents (Oppenheimer et al., 2011) for each melt inclusion. See Figure 4 for derivation of the lava lake $\mathrm{Fe}^{3+} / \Sigma \mathrm{Fe}$ ratio. The results of gas-melt equilibrium modelling are shown for basanite (blue curve), tephriphonolite (yellow curve) and phonolite (red curve) compositions. Errors in sulphur measurements are from Oppenheimer et al (2011); errors in $\mathrm{Fe}^{3+} / \Sigma \mathrm{Fe}$ ratios are discussed in the SI. Starting conditions for each run are detailed in Table 4.

Figure 7: Calculated $f_{2}$ (as $\Delta \mathrm{NNO}$ ) and volcanic gas redox-couple ratio as a function of pressure, shown in the context of a schematic representation of the Erebus plumbing system. The results of gas-melt equilibrium modelling are shown for basanite (blue curve), tephriphonolite (yellow curve) and phonolite (red curve) compositions. The red star represents the lava lake conditions as determined by surface gas measurements (Oppenheimer et al., 2011; Moussallam et al., 2012). 

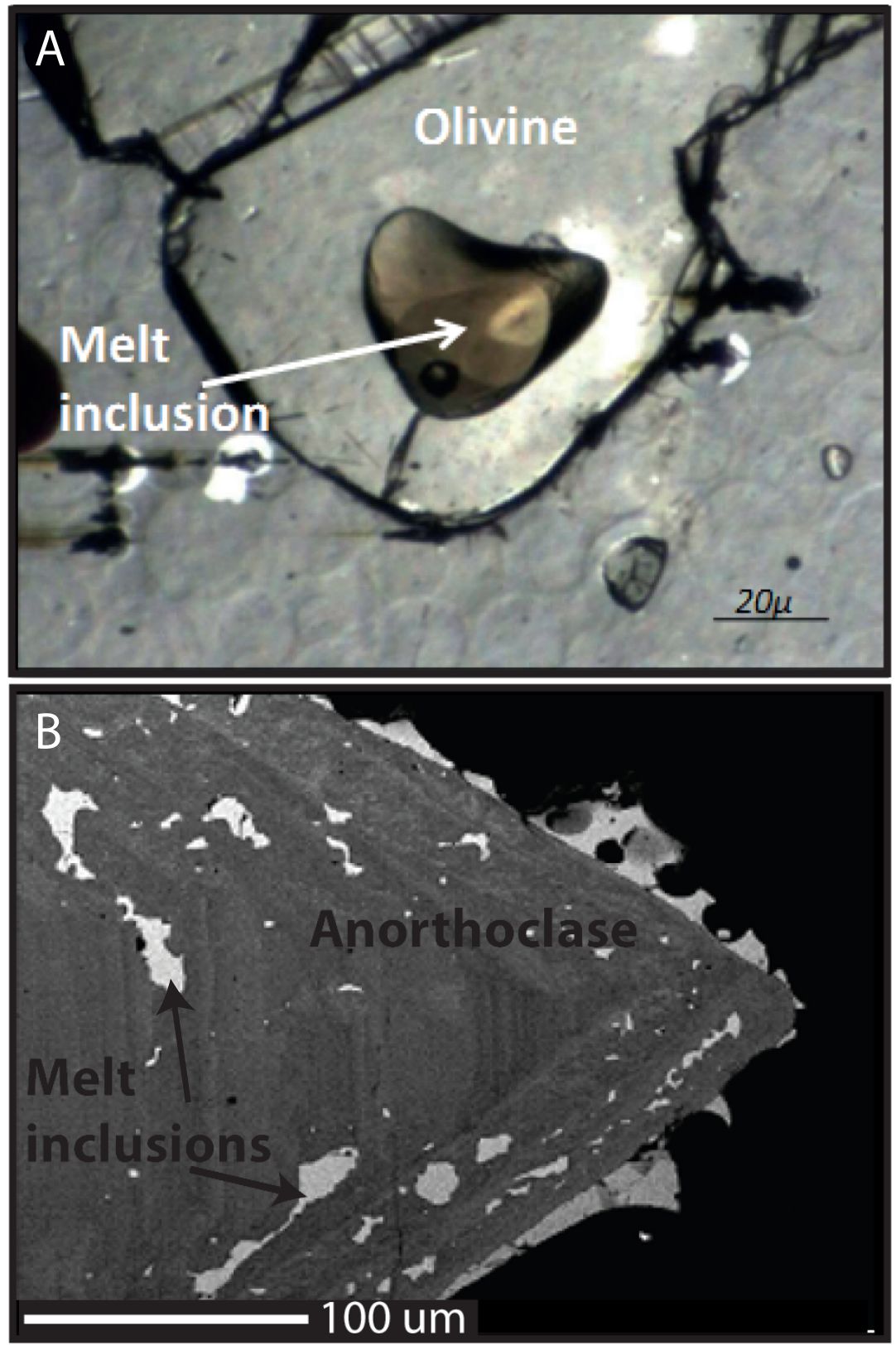

Moussallam et al., Figure 1 

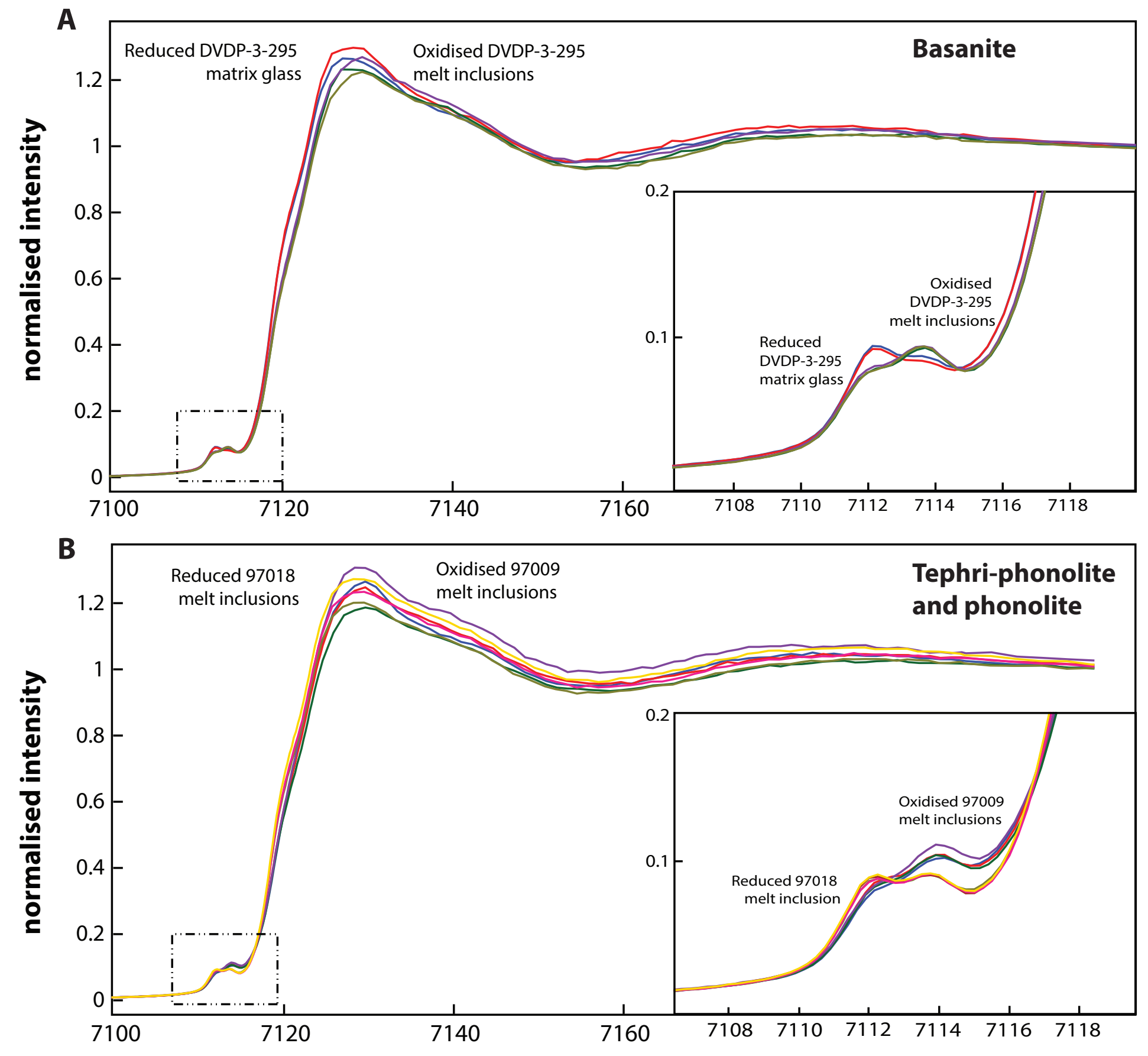

C

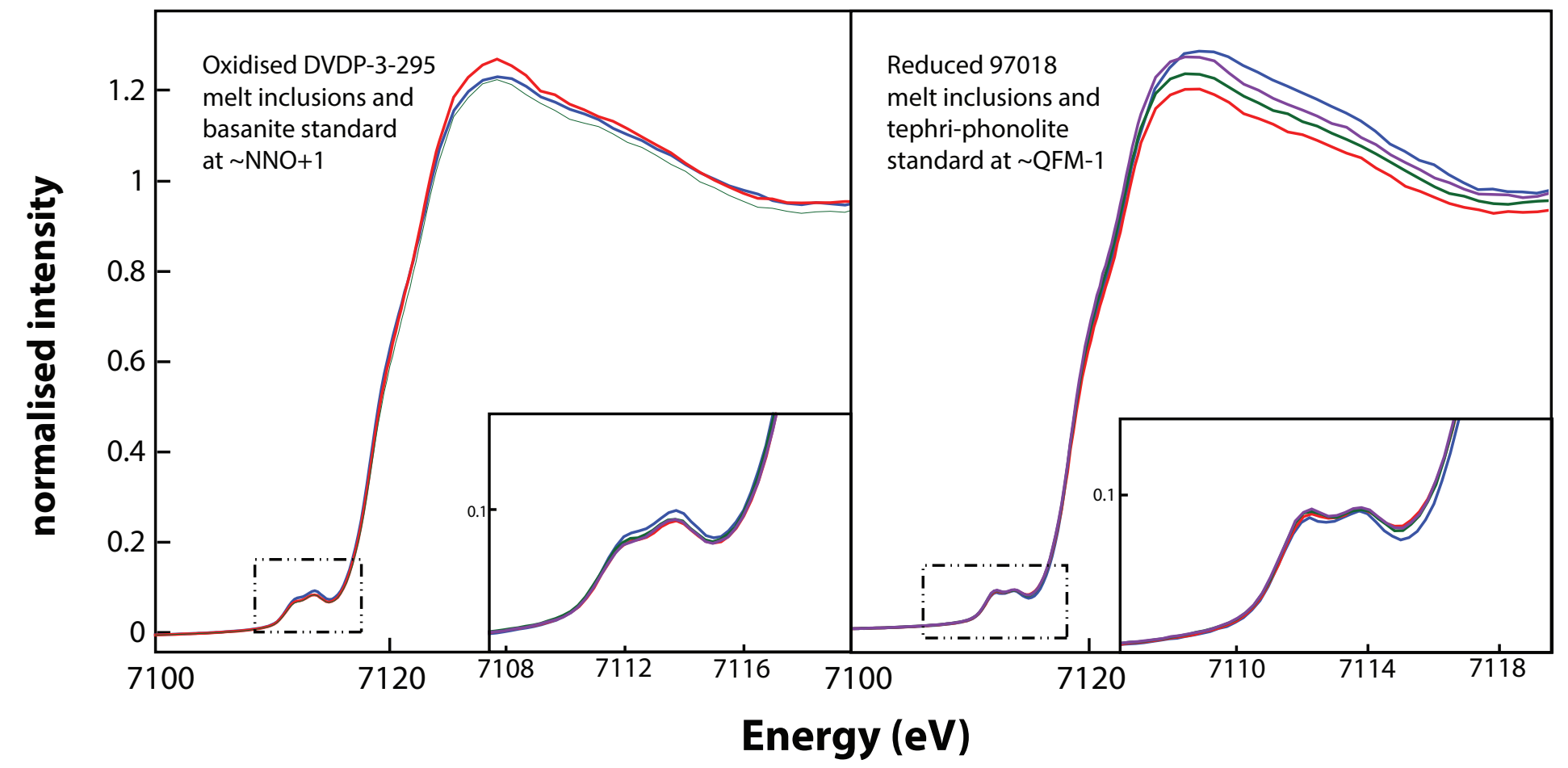

Moussallam et al., Figure 2 

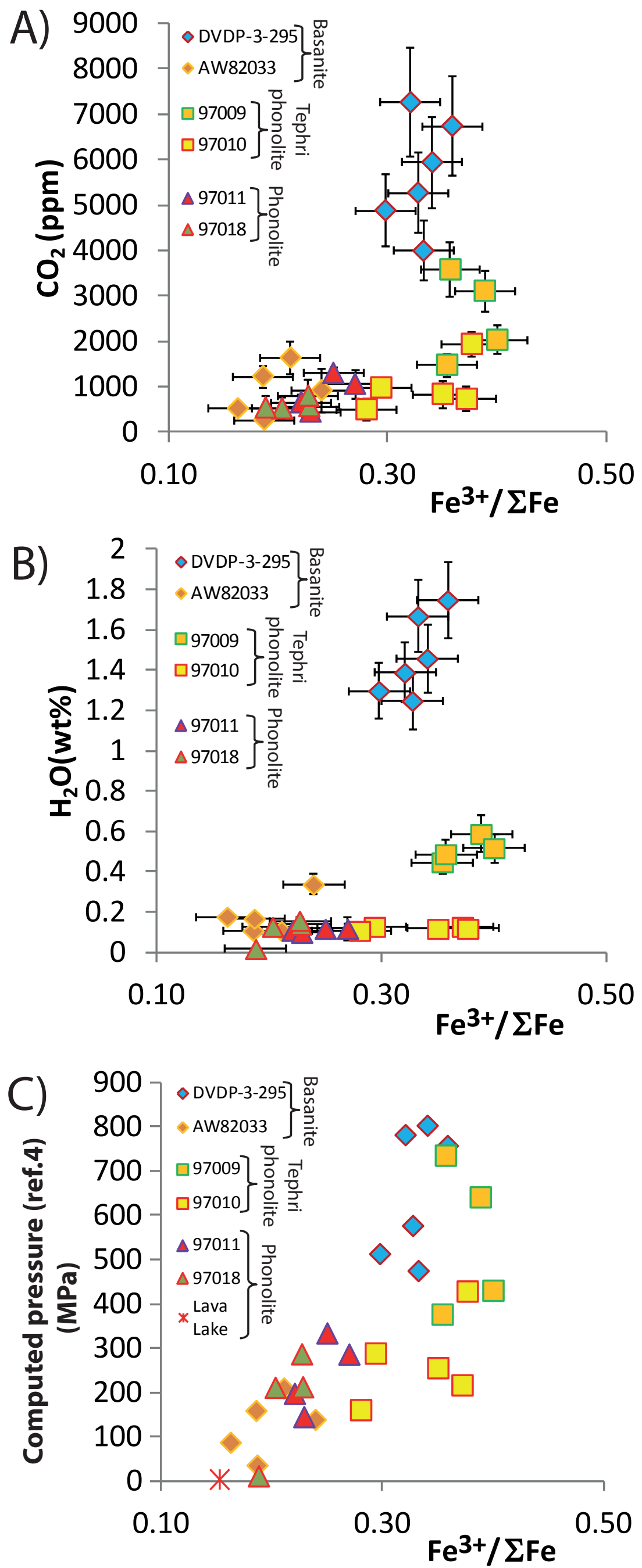

Moussallam et al., Figure 3 


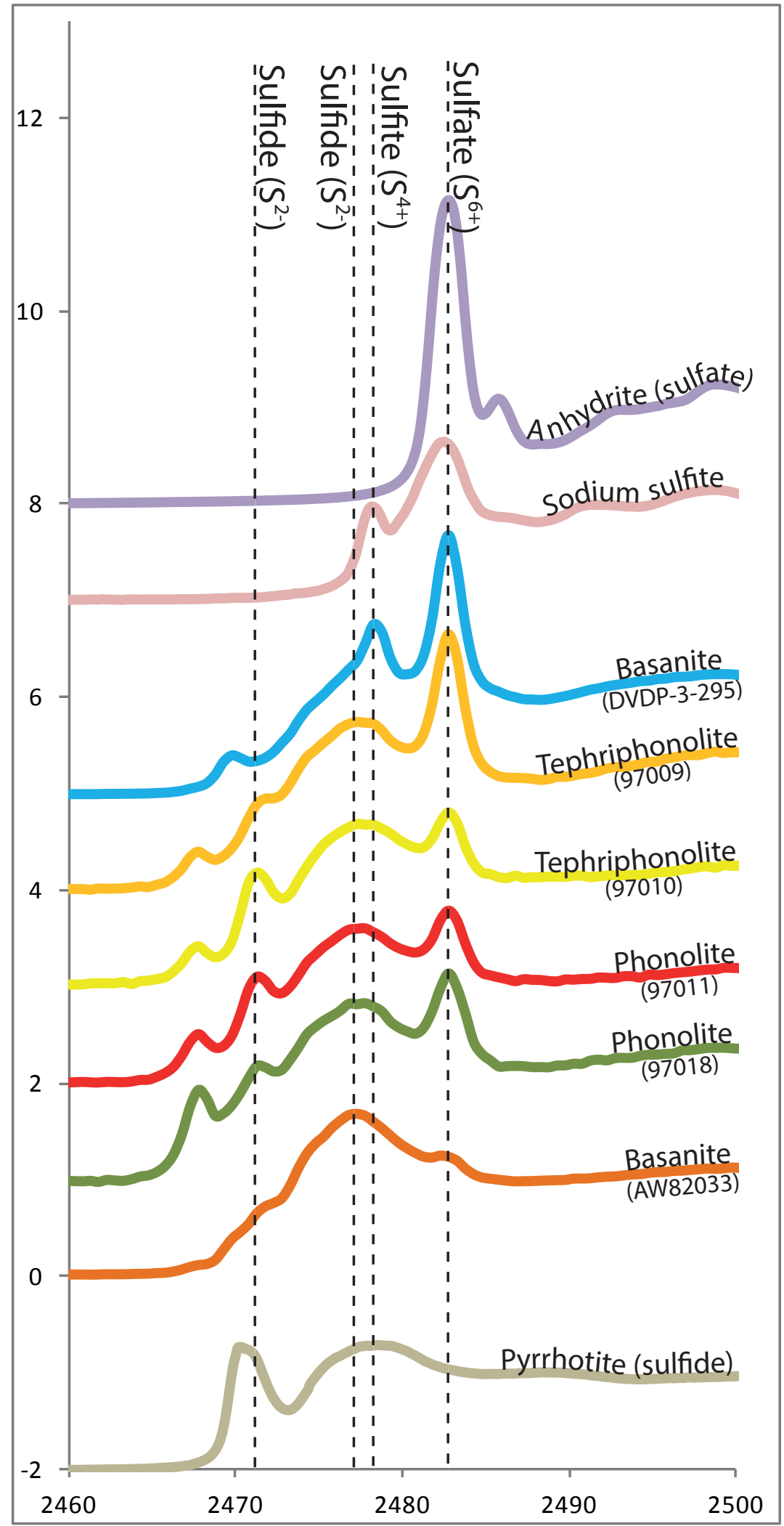

Moussallam et al., Figure 4 


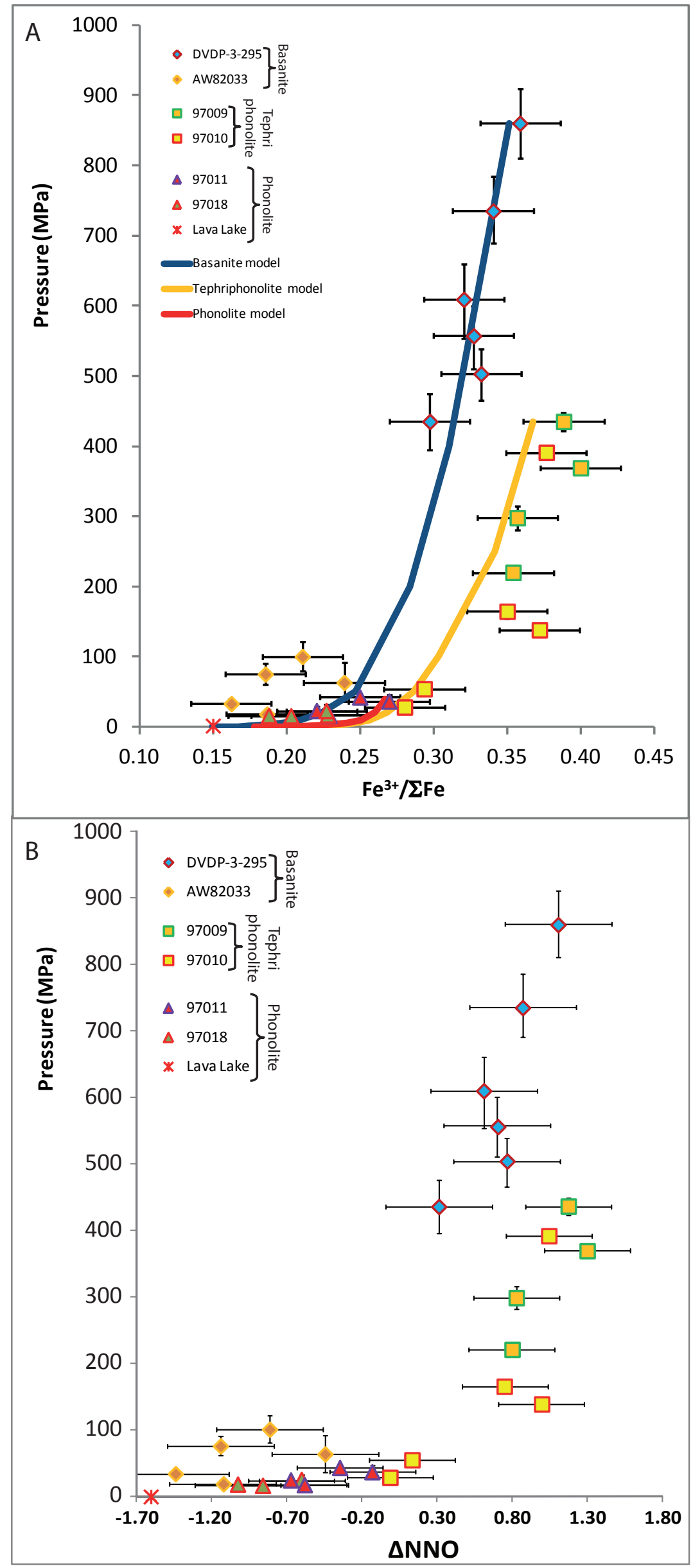

Moussallam et al., Figure 5 


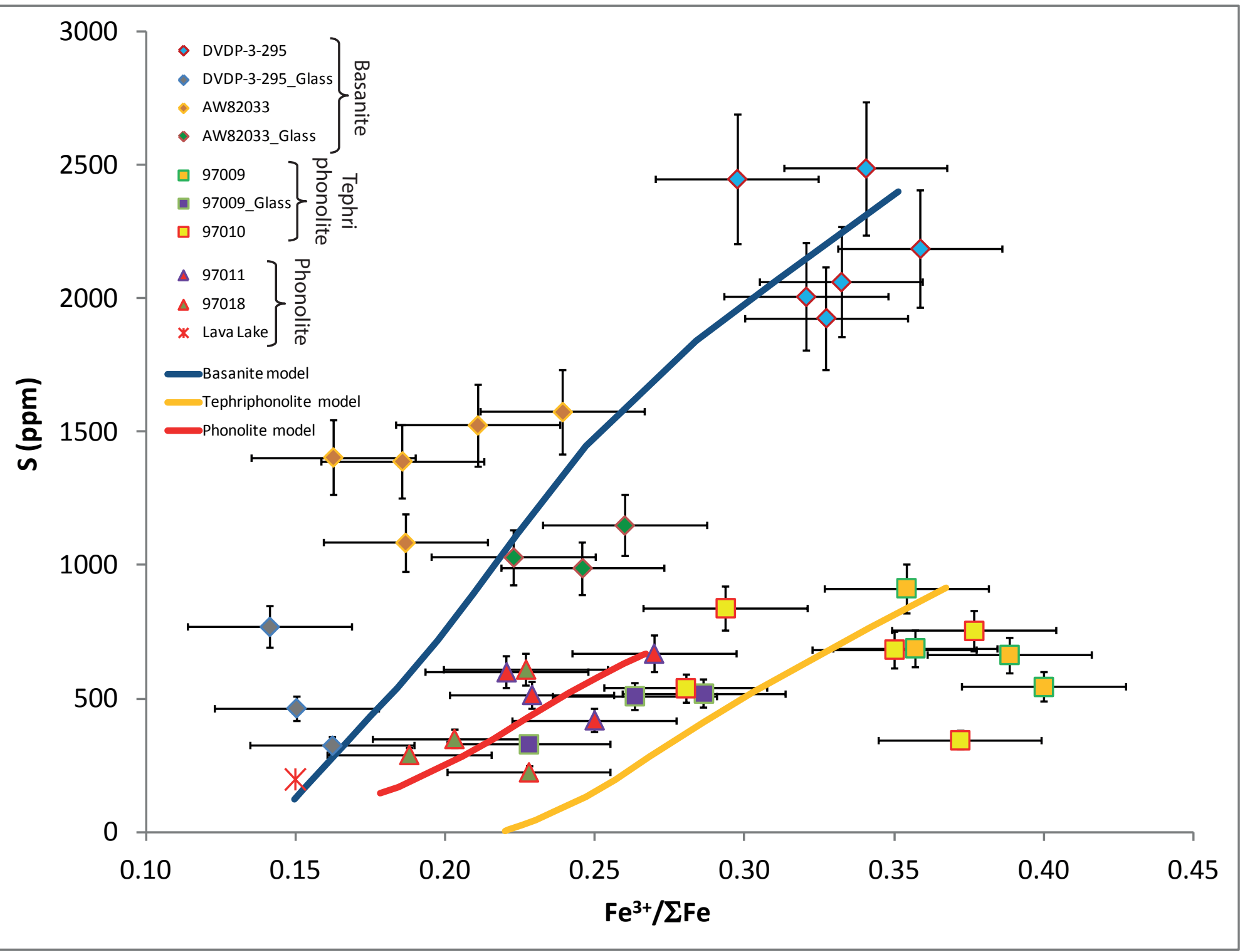

Moussallam et al., Figure 6 
Table 1: $\mathrm{Fe}^{3+} / \Sigma \mathrm{Fe}$ of glass standards determined by: * wet chemistry and tcalculated from imposed $\mathrm{fO}_{2}$ by controlled $\mathrm{CO}_{2} / \mathrm{CO}$ gas flux in furnace using equation from Kress and Carmichael, (1991) for the tephriphonolite and our modified equation (see method) for the basanite.

\begin{tabular}{lccc}
\hline Sample & $\mathrm{Fe}^{3+} / \Sigma \mathrm{Fe}^{*}$ & Error & $\mathrm{Fe}^{3+} / \Sigma \mathrm{Fe}^{\dagger}$ \\
\hline XANSTD_Ba_01_QFM-1 & 0.07 & 0.01 & 0.10 \\
XANSTD_Ba_02_QFM & 0.17 & 0.02 & 0.15 \\
XANSTD_Ba_03_NNO & 0.26 & 0.02 & 0.21 \\
XANSTD_Ba_04_NNO+1 & 0.37 & 0.03 & 0.30 \\
XANSTD_TP_01_QFM-1 & 0.16 & 0.01 & 0.13 \\
XANSTD_TP_03_NNO & 0.37 & 0.03 & 0.27 \\
XANSTD_TP_04_NNO+1 & 0.39 & 0.03 & 0.39 \\
\hline
\end{tabular}


Table 2. Volatile content centroid position, $\mathrm{Fe}^{3+} / \Sigma \mathrm{Fe}$ and calculated pressure for all melt inclusion and glasses analysed.

\begin{tabular}{|c|c|c|c|c|c|c|c|c|c|c|c|c|c|}
\hline $\begin{array}{c}\text { Melt } \\
\text { inclusion/Glass }\end{array}$ & Host & Centroid & $\mathrm{Fe}^{3+} / \Sigma \mathrm{Fe}$ & $\begin{array}{l}\text { Error on } \\
\mathrm{Fe}^{3+} / \Sigma \mathrm{Fe}\end{array}$ & $\begin{array}{l}\text { Pressure* } \\
\text { (bar) }\end{array}$ & $\begin{array}{l}\text { Pressure } \\
\text { (bar) }\end{array}$ & $\begin{array}{c}\text { Error on } \\
\text { pressure } \\
\text { (bar) }\end{array}$ & $\begin{array}{c}* * S \\
(\mathbf{p p m})\end{array}$ & $\begin{array}{c}* * * \text { Error } \\
\text { on } S \\
(\mathrm{ppm})\end{array}$ & $\begin{array}{l}{ }^{* *} \mathrm{CO}_{2} \\
\text { (ppm) }\end{array}$ & $\begin{array}{c}* * \text { Error } \\
\text { on } \mathrm{CO}_{2} \\
\text { (ppm) }\end{array}$ & $\begin{array}{l}{ }^{* *} \mathrm{H}_{2} \mathrm{O} \\
(\mathrm{wt} \%)\end{array}$ & $\begin{array}{c}* * \text { Error } \\
\text { on } \mathrm{H}_{2} \mathrm{O} \\
\text { (wt\%) }\end{array}$ \\
\hline DVDP-3-295j & olivine & 7112.73 & 0.297 & 0.027 & 5136.2 & 4350 & 400 & 2448 & 245 & 4890 & 790 & 1.30 & 0.14 \\
\hline DVDP-3-295c & olivine & 7112.77 & 0.340 & 0.027 & 8033.9 & 7350 & 500 & 2488 & 249 & 5950 & 1000 & 1.46 & 0.17 \\
\hline DVDP-3-295q & olivine & 7112.76 & 0.327 & 0.027 & 5772.2 & 5570 & 470 & 1927 & 193 & 5280 & 880 & 1.25 & 0.14 \\
\hline DVDP-3-295b & olivine & 7112.76 & 0.332 & 0.027 & 4753.8 & 5030 & 380 & 2062 & 206 & 4000 & 660 & 1.67 & 0.18 \\
\hline DVDP-3-295R & olivine & 7112.75 & 0.320 & 0.027 & 7823.2 & 6090 & 560 & 2007 & 201 & 7270 & 1200 & 1.39 & 0.15 \\
\hline DVDP-3-295g & olivine & 7112.79 & 0.359 & 0.027 & 7577.3 & 8600 & 500 & 2187 & 219 & 6750 & 1090 & 1.75 & 0.19 \\
\hline DVDP-3-295-G3 & & 7112.57 & 0.150 & 0.027 & & & & 465 & 47 & ND & & 0.23 & 0.03 \\
\hline DVDP-3-295-G2 & & 7112.56 & 0.141 & 0.027 & & & & 770 & 77 & ND & & 0.34 & 0.04 \\
\hline DVDP-3-295-G1 & & 7112.58 & 0.162 & 0.027 & & & & 325 & 32 & ND & & 0.26 & 0.03 \\
\hline AW82033h & olivine & 7112.66 & 0.239 & 0.027 & 1393.4 & 630 & 280 & 1575 & 157 & 930 & 470 & 0.34 & 0.05 \\
\hline AW82033c & olivine & 7112.63 & 0.211 & 0.027 & 2101.5 & 1000 & 210 & 1525 & 152 & 1650 & 350 & 0.11 & 0.02 \\
\hline AW82033a & olivine & 7112.58 & 0.163 & 0.027 & 876.74 & 330 & 70 & 1405 & 140 & 530 & 110 & 0.18 & 0.02 \\
\hline AW82033d & olivine & 7112.60 & 0.186 & 0.027 & 1594.2 & 750 & 150 & 1390 & 139 & 1240 & 240 & 0.11 & 0.02 \\
\hline AW82033g & olivine & 7112.61 & 0.187 & 0.027 & 361.6 & 180 & 65 & 1085 & 108 & 280 & 110 & 0.17 & 0.02 \\
\hline AW82033_G1 & & 7112.64 & 0.223 & 0.027 & & & & 1030 & 103 & 110 & 50 & 0.10 & 0.01 \\
\hline AW82033_G3 & & 7112.69 & 0.260 & 0.027 & & & & 1150 & 115 & 10 & 5 & 0.01 & 0.001 \\
\hline AW82033_G2 & & 7112.67 & 0.246 & 0.027 & & & & 990 & 99 & 60 & 30 & 0.10 & 0.01 \\
\hline $97009 a$ & olivine & 7113.14 & 0.388 & 0.027 & 6417.9 & 4350 & 130 & 665 & 66 & 3120 & 450 & 0.59 & 0.09 \\
\hline 97009d & olivine & 7113.10 & 0.354 & 0.027 & 3771.5 & 2200 & 80 & 915 & 91 & 1490 & 260 & 0.45 & 0.06 \\
\hline $97009 \mathrm{~g}$ & olivine & 7113.16 & 0.400 & 0.027 & 4309 & 3690 & 90 & 545 & 54 & 2040 & 310 & 0.52 & 0.07 \\
\hline 97009j & olivine & 7113.11 & 0.357 & 0.027 & 7359.6 & 2980 & 170 & 690 & 69 & 3590 & 600 & 0.49 & 0.07 \\
\hline 97009_G1 & & 7113.03 & 0.286 & 0.027 & & & & 520 & 52 & 170 & 90 & 0.15 & 0.02 \\
\hline 97009_G2 & & 7112.96 & 0.228 & 0.027 & & & & 330 & 33 & 190 & 100 & 0.12 & 0.01 \\
\hline 97009_G3 & & 7113.00 & 0.263 & 0.027 & & & & 510 & 51 & 220 & 120 & 0.12 & 0.01 \\
\hline 97010f & olivine & 7113.12 & 0.372 & 0.027 & 2173.1 & 1380 & 90 & 345 & 34 & 740 & 270 & 0.13 & 0.02 \\
\hline
\end{tabular}




\begin{tabular}{|c|c|c|c|c|c|c|c|c|c|c|c|c|c|}
\hline $97010 \mathrm{~g}$ & olivine & 7113.10 & 0.350 & 0.027 & 2559.8 & 1645 & 105 & 685 & 68 & 850 & 300 & 0.12 & 0.02 \\
\hline 97010d & olivine & 7113.03 & 0.294 & 0.027 & 2891.9 & 540 & 65 & 840 & 84 & 990 & 180 & 0.13 & 0.02 \\
\hline $97010 b$ & olivine & 7113.13 & 0.377 & 0.027 & 4291.2 & 3910 & 90 & 755 & 75 & 1950 & 270 & 0.12 & 0.02 \\
\hline $97010 c$ & olivine & 7113.02 & 0.280 & 0.027 & 1613.5 & 280 & 85 & 540 & 54 & 510 & 240 & 0.11 & 0.02 \\
\hline 97011b & olivine & 7112.95 & 0.220 & 0.027 & 1981.1 & 230 & 55 & 600 & 60 & 670 & 180 & 0.11 & 0.03 \\
\hline 97011c & olivine & 7112.96 & 0.229 & 0.027 & 1455.3 & 165 & 55 & 515 & 51 & 460 & 180 & 0.1 & 0.02 \\
\hline 97011a & olivine & 7112.98 & 0.250 & 0.027 & 3345.2 & 425 & 35 & 420 & 42 & 1310 & 130 & 0.12 & 0.02 \\
\hline 97011f & olivine & 7113.01 & 0.270 & 0.027 & 2868.6 & 365 & 95 & 670 & 67 & 1070 & 320 & 0.12 & 0.06 \\
\hline 97018f & anorthoclase & 7112.93 & 0.203 & 0.027 & 2117.9 & 155 & 65 & 350 & 35 & 530 & 240 & 0.13 & 0.01 \\
\hline 97018a & anorthoclase & 7112.96 & 0.228 & 0.027 & 2129.9 & 170 & 70 & 225 & 22 & 580 & 260 & 0.14 & 0.01 \\
\hline $97018 c$ & anorthoclase & 7112.91 & 0.188 & 0.027 & 119.21 & 160 & 75 & 290 & 29 & 550 & 270 & 0.02 & 0.003 \\
\hline $97018 e$ & anorthoclase & 7112.96 & 0.227 & 0.027 & 2873.9 & 230 & 90 & 610 & 61 & 810 & 350 & 0.16 & 0.02 \\
\hline $\begin{array}{l}\text { Basanite std. } \\
\text { (OFM-1) }\end{array}$ & & 7112.52 & 0.100 & 0.027 & & & & & & & & & \\
\hline $\begin{array}{l}\text { Basanite std. } \\
\text { (QFM) }\end{array}$ & & 7112.59 & 0.152 & 0.027 & & & & & & & & & \\
\hline $\begin{array}{l}\text { Basanite std. } \\
\text { (NNO) }\end{array}$ & & 7112.67 & 0.205 & 0.027 & & & & & & & & & \\
\hline $\begin{array}{l}\text { Basanite std. } \\
(\mathrm{NNO}+1)\end{array}$ & & 7112.75 & 0.304 & 0.027 & & & & & & & & & \\
\hline $\begin{array}{l}\text { Tephriphonolite } \\
\text { std. }\end{array}$ & & 7112.87 & 0.132 & 0.027 & & & & & & & & & \\
\hline $\begin{array}{l}\text { Tephriphonolite } \\
\text { std. (NNO) }\end{array}$ & & 7112.97 & 0.267 & 0.027 & & & & & & & & & \\
\hline $\begin{array}{l}\text { Tephriphonolite } \\
\text { std. (NNO+1) }\end{array}$ & & 7113.16 & 0.390 & 0.027 & & & & & & & & & \\
\hline
\end{tabular}

*Pressure estimate from Oppenheimer et al., (2011). †Pressure recalculated by this study. ** data from Eschenbacher, (1998) ; Oppenheimer et al., (2011); ***error assumed to be 10\%; ND not detected 
Table 3. $\mathrm{Fe}^{3+} / \mathrm{LF}$ from wet chemistry calibration and $\triangle N N O$ determined by calibrating the centroid position using the standard's $\triangle N N O$ values (as imposed by controlled $\mathrm{CO}_{2} / \mathrm{CO}_{\text {gas }}$ flux in furnace).

\begin{tabular}{|c|c|c|c|c|}
\hline $\begin{array}{c}\text { Melt } \\
\text { inclusion/Glass }\end{array}$ & $\triangle$ NNO & $\begin{array}{c}\text { Error on } \\
\Delta \text { NNO }\end{array}$ & $\mathrm{Fe}^{3+} / \Sigma \mathrm{fe}$ & $\begin{array}{l}\text { Error on } \\
\mathrm{Fe}^{3+} / \Sigma \mathrm{Fe}\end{array}$ \\
\hline DVDP-3-295j & 0.316 & 0.355 & 0.297 & 0.039 \\
\hline DVDP-3-295c & 0.874 & 0.355 & 0.359 & 0.039 \\
\hline DVDP-3-295q & 0.702 & 0.355 & 0.340 & 0.039 \\
\hline DVDP-3-295b & 0.767 & 0.355 & 0.347 & 0.039 \\
\hline DVDP-3-295R & 0.615 & 0.355 & 0.330 & 0.039 \\
\hline DVDP-3-295g & 1.110 & 0.355 & 0.385 & 0.039 \\
\hline DVDP-3-295-G3 & -1.596 & 0.355 & 0.085 & 0.039 \\
\hline DVDP-3-295-G2 & -1.712 & 0.355 & 0.072 & 0.039 \\
\hline DVDP-3-295-G1 & -1.440 & 0.355 & 0.102 & 0.039 \\
\hline AW82033h & -0.441 & 0.355 & 0.213 & 0.039 \\
\hline AW82033c & -0.810 & 0.355 & 0.172 & 0.039 \\
\hline AW82033a & -1.436 & 0.355 & 0.103 & 0.039 \\
\hline AW82033d & -1.136 & 0.355 & 0.136 & 0.039 \\
\hline AW82033g & -1.123 & 0.355 & 0.137 & 0.039 \\
\hline AW82033_G1 & -0.654 & 0.355 & 0.189 & 0.039 \\
\hline AW82033_G3 & -0.173 & 0.355 & 0.243 & 0.039 \\
\hline AW82033_G2 & -0.355 & 0.355 & 0.223 & 0.039 \\
\hline $97009 a$ & 1.177 & 0.285 & 0.416 & 0.028 \\
\hline 97009d & 0.799 & 0.285 & 0.379 & 0.028 \\
\hline 97009g & 1.303 & 0.285 & 0.429 & 0.028 \\
\hline 97009j & 0.832 & 0.285 & 0.382 & 0.028 \\
\hline 97009_G1 & 0.057 & 0.285 & 0.306 & 0.028 \\
\hline 97009_G2 & -0.584 & 0.285 & 0.243 & 0.028 \\
\hline 97009_G3 & -0.196 & 0.285 & 0.281 & 0.028 \\
\hline 97010f & 0.996 & 0.285 & 0.398 & 0.028 \\
\hline $97010 \mathrm{~g}$ & 0.755 & 0.285 & 0.375 & 0.028 \\
\hline 97010d & 0.137 & 0.285 & 0.314 & 0.028 \\
\hline 97010b & 1.048 & 0.285 & 0.404 & 0.028 \\
\hline $97010 \mathrm{c}$ & -0.010 & 0.285 & 0.299 & 0.028 \\
\hline $97011 b$ & -0.666 & 0.285 & 0.235 & 0.028 \\
\hline 97011c & -0.573 & 0.285 & 0.244 & 0.028 \\
\hline 97011a & -0.343 & 0.285 & 0.266 & 0.028 \\
\hline 97011f & -0.126 & 0.285 & 0.288 & 0.028 \\
\hline 97018f & -0.857 & 0.285 & 0.216 & 0.028 \\
\hline $97018 a$ & -0.584 & 0.285 & 0.243 & 0.028 \\
\hline $97018 c$ & -1.023 & 0.285 & 0.199 & 0.028 \\
\hline $97018 e$ & -0.595 & 0.285 & 0.242 & 0.028 \\
\hline
\end{tabular}


Table 4. Starting conditions used in for each model run. *Sulphur capacity calculated using O'neill and Mavrogenes, (2002)

\begin{tabular}{lccccccc}
\hline \multicolumn{1}{c}{ Model } & $\begin{array}{c}\text { Pressure } \\
(\mathbf{b a r})\end{array}$ & $\begin{array}{c}\text { Temperature } \\
\left({ }^{\circ} \mathbf{K}\right)\end{array}$ & $\begin{array}{c}\mathbf{F e O} \\
(\mathbf{w t} \%)\end{array}$ & $\mathbf{l n C s} *$ & $\begin{array}{c}\mathbf{S} \\
(\mathbf{p p m})\end{array}$ & $\begin{array}{c}\mathbf{f H}_{\mathbf{2}} \mathbf{O} \\
(\text { bar) }\end{array}$ & $\begin{array}{c}\boldsymbol{f H}_{\mathbf{2}} \\
\text { (bar) }\end{array}$ \\
\hline Basanite & 8600 & 1473.15 & 10.26 & -1.42 & 2400 & 220 & 0.4 \\
Tephriphonolite & 4350 & 1373.15 & 7.5 & -3.94 & 915 & 70 & 0.12 \\
Phonolite & 400 & 1273.15 & 5.43 & -5.39 & 670 & 10 & 0.06
\end{tabular}

